\title{
Material Modification by using Neural Network for Optimal Mixing
}

\author{
Rugat Y. Khamidullin ${ }^{1}$ \\ ${ }^{1}$ Department of Higher mathematics and natural science, synergy University», Russia
}

\begin{abstract}
One of the most important tasks in construction, both in technical and aesthetic aspects is to increase the durability of external walls of buildings and structures. In connection with the development of energy-efficient construction, the construction of a multilayer wall with high performance properties is increasingly used due to the use of ceramic clinker brick as a decorative protective layer. At the same time, such a brick requires high-quality raw materials and high firing temperature, which leads to a significant increase in its cost. Therefore, currently, as a decorative facade cladding is used ceramic facing brick. An important component of brick structures is also a mortar that connects the elements of the brick in the masonry. At the same time, the porous structure of ceramic face brick and cement masonry mortars leads in operation to the penetration of moisture, both in the surface and in the deeper layers of masonry, destroying it, especially in conditions of alternating temperatures; in addition, the formation of efflorescence causes a decrease in the technical and decorative properties of brick structures by neural network.
\end{abstract}

Key words : neural network, ceramic bricks, external walls, modification, building construction.

\section{INTRODUCTION}

Traditional water repellents, as a rule, do not provide set operating parameters of the brickwork. In this regard, the technology of construction production requires a new approach to the modification of ceramic face brick on nano-and submicro with protective substances action and masonry mortar based on multicomponent cements additives by plasticizing admixtures-air action to improve the performance of the outer walls of brick structures [1-3].

Generalization of the results of research in the field of construction materials science shows that the increase in durability of external walls of buildings and structures is largely achieved due to their surface modification with hydrophobic nano-liquids of penetrating and annular action, as well as the use of modified multicomponent cement in masonry solutions with a reduced clinker factor up to 40\% [4]. Therefore, relevant studies can be considered aimed at solving the problem of significantly reducing the salinity of brickwork of external walls of buildings and structures and improving their operational reliability.

\section{MATERIALS AND METHODS}

The experimental results were carried out using a complex of modern methods of physical and chemical analysis, in particular, laser granulometry, x-ray diffractometry, scanning electron microscopy, thermogravimetry, etc. Determination of physical and technical, physical and mechanical and operational properties of ceramic bricks and modified mortar were carried out in accordance with current national and European standards, as well as generally accepted methods. Optimization of the composition of nanoridins and complex additives was carried out using experimental statistical methods of experiment planning [5].

For the construction of masonry exterior walls of buildings and structures are widely used traditional masonry mortars, characterized by sufficient density, strength of adhesion to the base and the design mark of strength [6]. At the same time, owing to the increased water absorption in a laying seam the dehydrated layer of a solution that leads to emergence of hair cracks and destruction of integrity of the laying can be formed [7]. On the other hand, the use of traditional solutions based on Portland cement for General construction purposes and the addition of lime, as a plasticizer, leads to the formation of efflorescence on the surface of the walls. In order to improve the technological and construction-technical properties of masonry solutions, additives of weather-activate action are introduced into their composition, which allow to increase resistance to the effects of multiple cycles of freezing, acting as "stress dampers" [8-10].

One of the effective ways to improve the performance properties of brickwork is also the use of multicomponent cements for mortars. The expediency of using such binders with a high content of active mineral additives of hydraulic and this action allows you to effectively manage the processes of structure formation of the cement matrix and obtain materials with predetermined properties.

Analysis of the known patterns in the field of building materials allows us to advance a scientific hypothesis about the possibility of surface modification of ceramic facing brick water-repellent nano-fluids, which due to the penetrating and climatic actions give the structure of the surface uniform and more dense in nature, and the creation of low-emission multi-component cements for masonry, modified additives plasticizing steps, which provide the directed formation of microstructure of cement matrix solution, that determines the quality of masonry without salting and improves the 
operational reliability of the external walls of buildings and structures [11].

For carrying out researches the ceramic face hollow brick Klpr-1NF and product ceramic clinker hollow KKL LLC "Brick holding" (Tula) and PJSC Razdolsky ceramic plant TM "Euroton". As protective coatings, hydrophobizers based on an aqueous solution of silicon resin (GF-1), acrylic polymers (GF-2), organosilicon compounds (GF-3) and silically varnish (PMFS) KO-85 were used. To improve the performance properties of ceramic bricks developed hydrophobic nano-liquid, which includes PMFS, aluminum oxide powder and iron oxide and aluminum oxide nanopowder.

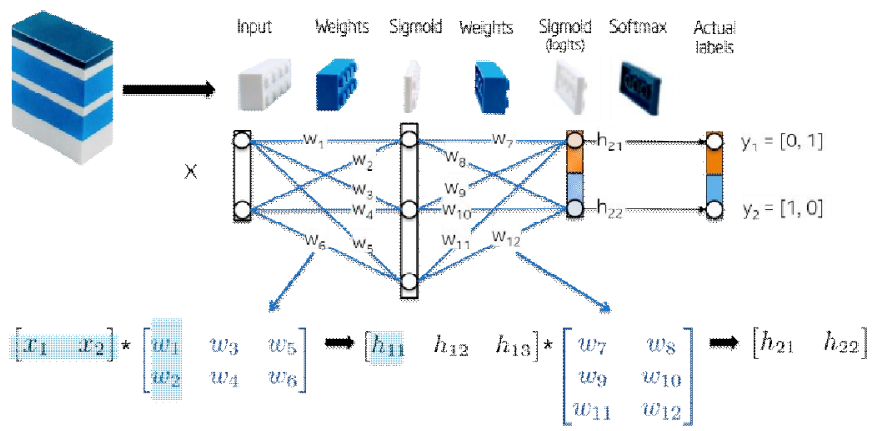

Figure 1 : Model of neural network for analyzing bricks and building materials

Figure 1 shows us the model of neural network.

Nanodispersed alumina powder (Sigma-Aldrich Chemie $\mathrm{GmbH}$, Germany) contains particles of 30-40 nm, true density is $0.12 \mathrm{~g} / \mathrm{cm} 3$, specific surface area $-70 \mathrm{~m} 2 / \mathrm{g}$ [12].

As can be seen from the micrograph the salts of tenardite are determined by a friable fine-crystalline structure, and arkanite is crystallized by plate-like aggregates ( $10 . .20$ microns), separate groups (Figure 1, b). The presence of $\mathrm{Na} 2 \mathrm{SO} 4$ and $\mathrm{K} 2 \mathrm{SO} 4$ salt phases is confirmed by x-ray spectral analysis (Figure 2, b, d).
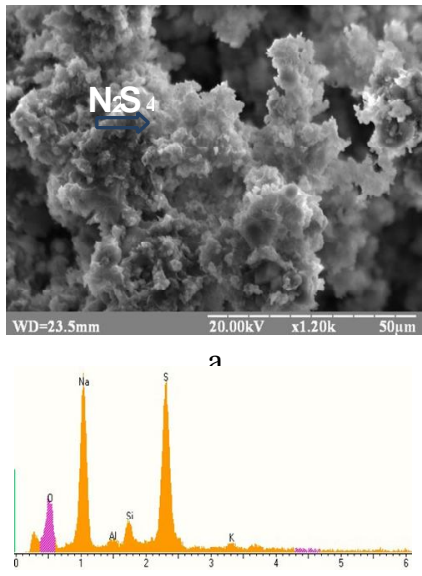

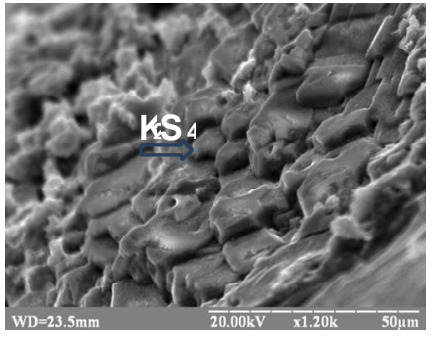

h

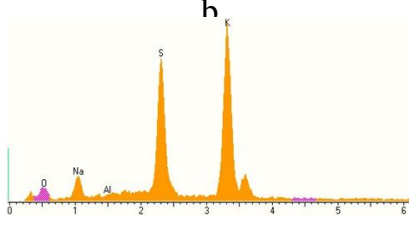

d
Figure 2 : Microstructure $(\mathrm{a}, \mathrm{b})$ and $\mathrm{x}$-ray characteristic radiation spectra $(c, d)$ of ceramic face brick

Figure 2 shows us microstructure final mixing of building material.
Due to the increased content of $\mathrm{K} 2 \mathrm{O}$ in the efflorescence, the sulfate anion binds to form the mineral syngenite. It can be the reason of destructive phenomena in a matrix of a brick, and in General and in a laying.

The results of experimental tests have established that for ceramic face brick, the surface of which is treated with PMFS, frost resistance increases by 15 cycles, and for the surface coated with GF-2-by 20 cycles compared with brick without hydrophobizer (frost resistance mark F50). By electron microscopy it was found that after alternate freezing and thawing on the surface of the brick treated with a hydrophobizer based on PMFS, intensive formation of microcracks is observed, which leads to an increase in water absorption by $42 \%$. For the brick modified by GF- 2 and GF-3, cracks on the surface of the sample were formed locally with a smaller opening, which led to an increase in water absorption by $28-22 \%$. This indicates that the studied coatings based on traditional hydrophobizers can't be used to protect brick structures operating in conditions of high humidity, as well as the impact of cycles of alternate freezing and thawing [13].

To improve the performance properties of ceramic face brick, the influence of hydrophobic substances containing highly active $\mathrm{Al} 2 \mathrm{O} 3$ nanoparticles was studied by the method of mathematical planning of the experiment. Experimental studies of the effect of nano-liquids on the properties of ceramic bricks were carried out according to the plan of a two-factor three-level experiment, the content of PMFS (CO-85) $\quad(\mathrm{X} 1=30 ; 35 ; 40$ wt.\%) and the amount of nanopowder $\mathrm{Al} 2 \mathrm{O} 3(\mathrm{X} 2=0 ; 0.5 ; 1.0$ wt.\% ) (respectively, the content of aluminum oxide and iron was 55...65\%). By results of researches the equations of regression of water absorption (Ywm) and capillary tightening (Yw) adequately describing dependence of indicators as criteria of optimization of system, from variable factors are received. On the basis of graphical interpretation of the obtained mathematical models, it was found that the optimal region of administration of nano- $\mathrm{Al} 2 \mathrm{O} 3$ is within $0.6 \ldots 0.8$ wt.\%. When modifying the surface of the nano-liquid water absorption is reduced to $1.2-1.6 \%$, the water absorption rate at capillary tightening up to $0.08-0.12 \mathrm{~kg} / \mathrm{m} 2 *$ year $^{0,5}$.

The method of flaw detection using a Karsten tube (Fig. 3, a, c) it was found that the lowest water absorption (0.002 $\mathrm{ml} / \mathrm{cm} 2$ ) after 2 hours of exposure is characterized by the surface of ceramic bricks, modified nano-liquid, whereas for bricks without coating- $0.15 \mathrm{ml} / \mathrm{cm} 2$. Based on these results, we can state the presence of an interesting regularity associated with the formation of the surface microstructure. In particular, by electron microscopy it was found that the surface of the sample of ceramic bricks without coating (Fig. 2, b) is inhomogeneous with protrusions and capillary micropores (10-15 microns). When the sample surface is impregnated with nano-liquid, the microstructure is leveled and compacted due to the penetration of nanoparticles into the pore structure of the material (Fig. 3, d). The effectiveness of the application of nano-fluid due to the free energy surface, and Dalmatovsky surface subscrive particles of nano-Al2O3 in the composition of a hydrophobizing substance. In this case, the pulling of water-soluble salts from the masonry is blocked. 


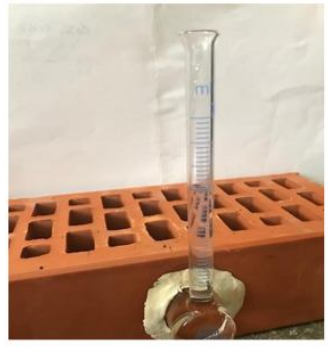

a
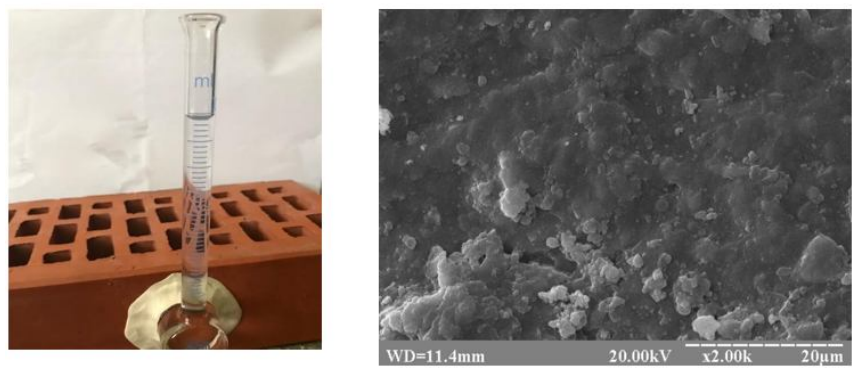

Figure 3 : Water absorption and microstructure of ceramic face brick: unmodified $(\mathrm{a}, \mathrm{b})$ and modified with nano-liquid $(\mathrm{c}, \mathrm{d})$

Figure 3 shows us the water absoption of ceramic face brick modified and unmodified.

Studies of weather resistance found that for uncoated ceramic face brick after 100 cycles of alternate drying and wetting, the loss of strength was $15.2 \%$; at the same time, cracks with a width of 2-3 $\mathrm{mm}$ were observed on the samples [14]. At the same time, for ceramic face brick, the surface of which is modified by nano-liquid, the loss of strength was $1.8 \%$ without cracking. It should be noted that for ceramic face brick modified with nano-liquid, the frost resistance increased by 50 cycles and reaches the F100 mark. Due to this, it can be argued that the nano-liquid significantly affects the change in the nature of the structure of the surface of the ceramic face brick to protect the brick construction structure and improve its performance properties. The main indicators of ceramic face brick, uncoated and modified nano-liquid are given in table. 1.

Table 1: Basic parameters of ceramic face brick modified with nano-liquid

\begin{tabular}{|l|l|l|l|}
\hline \multicolumn{1}{|c|}{ Indicator } & \multicolumn{1}{c|}{ Unit } & \multicolumn{2}{c|}{ Value } \\
\cline { 3 - 4 } & & $\begin{array}{c}\text { Control } \\
\text { sample } \\
\text { (uncovered) }\end{array}$ & $\begin{array}{c}\text { Sample } \\
\text { coated with } \\
\text { nano-liquid }\end{array}$ \\
\hline $\begin{array}{l}\text { Water } \\
\text { absorption }\end{array}$ & $\%$ & 16,5 & 1,2 \\
\hline $\begin{array}{l}\text { Capillary } \\
\text { tightening }\end{array}$ & $\mathrm{kg} / \mathrm{m}^{2} \cdot \mathrm{hour}^{0,5}$ & 2,2 & 0,08 \\
\hline $\begin{array}{l}\text { Weather } \\
\text { resistance - loss } \\
\text { of strength }\end{array}$ & $\%$ & 15,2 & 1,8 \\
\hline $\begin{array}{l}\text { Frost resistance: } \\
\text { - loss of } \\
\text { strength } \\
\text { - mass loss }\end{array}$ & $\%$ & 19,0 & 5,2 \\
\hline
\end{tabular}

By electron scanning microscopy, it was found that the microstructure and pore ring of hydrated cement stone based on MS 22.5 are significantly compacted by needle Aft phases [15-16]. The crystal structure of ettringite, calmative pores, promotes the synthesis of its strength with age of curing. Fine inclusions of calcite in the mass of the gel-like phase C-S-H allow to reduce the shrinkage deformation of cement stone. It should be noted that additives by plasticizing admixtures-air actions lead to the formation in the stone of a system of air closed pores with a diameter of 20-150 microns, separated from each other and built up with a cement mass of mineral components.

\section{CONCLUSION}

It was found that the highest porosity (21\%), water absorption $(16.5 \%)$ and capillary tightening $(2.2 \mathrm{~kg} / \mathrm{m} 2)$ is characterized by ceramic face brick, the lowest $(\mathrm{N}=13.6 \%$, $\mathrm{Wm}=5.2 \%, \mathrm{~W}=0.5 \mathrm{~kg} / \mathrm{m} 2 \mathrm{yd} 0.5)$ - ceramic clinker brick. Studies of salinization showed the formation of salts on the surface of the ceramic face brick, which are represented by an increased content of $\mathrm{SO} 3(51.2$ wt.\%) and alkaline oxides-Na2O (36.7 wt.\%), K2O (12.4 wt.\%). By x-ray diffraction and $\mathrm{x}$-ray analyses established the presence of salts of thenardier, Arcanite and Syngenta.

The lightness of mortar mixtures based on MS 22.5 is determined by the following indicators: grade grade P8, moisture holding capacity-97-98 \%, delamination-2-4\%. Modified masonry solutions of the design grade M100 are characterized by an average density of $1840 \mathrm{~kg} / \mathrm{m} 3$, reduced shrinkage $(\mathrm{NY}=0.26 \mathrm{~mm} / \mathrm{m})$, frost resistance (F75) and weather resistance. The modulus of elasticity of such a solution in comparison with a complex solution decreases from 28.7 to 15.9 GPA, and the Poisson's ratio increases from 0.14 to 0.17 , which reduces the possibility of cracking and improves the quality of masonry. For masonry solutions, due to air extraction, the yield of the modified mortar mixture increases by $16 \ldots 20 \%$, and cement consumption is reduced by $30 \ldots 40 \mathrm{~kg}$. Developed complex additive with antifreeze effect ( 0.06 masses.\% PV +1.5 wt.\% FC) allow to improve strength characteristics of a masonry solution at hardening in the conditions of the lowered positive and negative (to -15 0C) temperatures.

\section{REFERENCES}

1. Alperovich, I. A. Development of production of face brick of volume coloring / I. A. Alperovich, G. I. Votyeva, V. K. Kryukov / / Building materials. - 1992. No. 3-4. - Pp. 2-4.

2. Filatova, E. V. Front decorative ceramic brick on the basis of low-melting red-burned clay: dis.. tech. Sciences: 05.23.05 / Filatova Ekaterina Vladimirovna. Novocherkassk, 2004. - 149c.

3. Han, L. X. The Distinctive Charm of Coating-Architecture in the Modern Urban Development / L. X. Han, J. Han, F. M. Sun, Y. J. Huo / / 
Advanced Materials Research. - 2011. - Vols. 160-162. P. 880-885.

4. Kleerekoper, A. van den Dobbelsteen, E. van den Ham, T. Hordijk, C. Martin / / Urban Climate-2015. - Vol. 14-Pp. 290-300.

https://doi.org/10.1016/j.uclim.2015.09.002

5. Kleerekoper, L. Creating drafts in urban settings through colored facades: Exploring a new climate adaptation measure based on thermal stratification / L.

6. Mojsov, G. N. Development of multi-purpose additives for bulk coloring of ceramic products: dis... tech. Sciences: 05.23.05 / moysov Georgy Leonidovich. Stavropol, 2003. - 164 p.

7. Razgovorov, P. B. Scientific bases of creation of composite materials from technical and natural silicates: dis. ... d-RA tekhn. Sciences: 05.17.01. / Pavel Borisovich Razgovorov-Ivanovo, 2008, - 357 p.

8. Salakhov, A. M. Experience of surface treatment of ceramic materials for construction purposes / Building materials. - 2017. - No. 4. Pp. 42-46.

9. Zubekhin, A. P. Angoby on the basis of red-hot fusible clays / A. p. Zubekhin, N. D. Yatsenko, V. P. ratkova, E. O. ratkova, K. A. Verevkin / / Building materials. - 2009. - No. 3. Pp. 40-41.

10. Lubysheva, L. I., \& Abramov, R. A. (2014). Innovative model of olympic education of primary schoolchildren based on information and communication technologies. Teoriya i Praktika Fizicheskoy Kultury, (7), 87-89.

11. Rodnyansky, D. V, Abramov, R. A., Repin, M. L., \& Nekrasova, E. A. (2019). Estimation of innovative clusters efficiency based on information management and basic models of data envelopment analysis. International Journal of Supply Chain Management, 8(5), 929-936.

12. Rodnyansky, D., Abramov, R., Valeeva, G., Makarov, I., \& Levchegov, O. (2019). Methods to evaluate public administration efficiency: The case of the volga region. International Journal of Engineering and Advanced Technology, 8(5), 2261-2271.

13. Klyuev S.V., Bratanovskiy S.N., Trukhanov S.V., Manukyan H.A. Strengthening of concrete structures with composite based on carbon fiber // Journal of Computational and Theoretical Nanoscience. 2019. V.16. №7. P. $2810-2814$.

14. scenario analysis. International Journal of Advanced Trends in Computer Science and Engineering, 8(1.4 S1), 1-8. https://doi.org/10.30534/ijatcse/2019/0181.42019

15. Doke, A. R., Garla, N., \& Radha, D. (2019). Analysis of human gene-disease association as a social network. International Journal of Advanced Trends in Computer Science and Engineering, 8(4), 1062-1068. https://doi.org/10.30534/ijatcse/2019/12842019

16. Doshi, N. (2019). Analysis of efficient and privacy-preserving metering protocols for smart grid systems. International Journal of Advanced Trends in Computer Science and Engineering, 8(6), 2882-2886. https://doi.org/10.30534/ijatcse/2019/32862019 